\title{
Konstruksi Pendidikan Islam Berbasis Rahmatan Lil'alamin; Suatu Telaah Diskursif
}

\begin{abstract}
Ahmad Fauzi*
Abstract: Islamic education today, faced with increasingly crucial challenges, the view, not separated from the atmosphere of modernization and globalization. Therefore, the presence of Islamic education is required to play its role dynamically and is expected to provide social change in the midst of pluralistic society life. Thus to build Islamic education in Indonesia that can bring the vision of universal Islam, it is necessary paradigm of Islamic education based rahmatan lilalamin, by promoting several principles, among others; maintaining harmony, peace, mutual respect, liberation, not the contrary as domestication and social domestication. In that context, the educational portrait referred to, is seen as a socio-cultural enlightment. Therefore, the effort to build the paradigm of Islamic education in question is a necessity, this can be done by restoring the social values of Islamic education universally (kaffah), in addition to being dynamic (inclusive), through several stages, namely (a) build awareness inclusive by transmitting the whole system of religious social values such as ketauhidan, tolerance and fairness into the structure of the curriculum as culture domination and control. (b) reconstructing the Islamic educational paradigm from the perspective of indoctrination to participatory, (c) changing the ideological paradigm to being scientific by allowing the human mind to study and develop knowledge through his guidance.
\end{abstract}

Keywords: Construction, Islamic Education based on Rahmatan Lil, alamin

\section{A. Pendahuluan}

Secara sosiologis, lahirnya modernisme pada sekitar lima abad yang lalu telah mendominasi pandangan masyarakat diberbagai kehidupan sosial, baik pada aspek budaya, ekonomi, politik dan pendidikan. Pada aspek yang lain, modernism juga ditandai dengan kemenangan logika positivistik-rasionalistik di segala bidang kajian keilmuan, dan mulai digugat oleh kebanyakan orang. Pandangan dimaksud, tidak lepas dari logika positivistik dan rasionalistik dengan slogannya bahwa ilmu tersebut bebas nilai dan bersifat netral, karena itu nilai apapun yang ada di dalam pandangan masyarakat tidak boleh mempengaruhi perkembangan pengetahuan, dan kurang memperhatikan nilai-nilai agama dan kemanusiaan. Pandangan di atas dipersepsikan dapat membahayakan sendi-sendi kehidupan manusia, karena itu

* Dosen Fakultas Tarbiyah Institut Ilmu Keislaman Zainul Hasan Genggong Probolinggo Jawa Timur email: fauzi_nov4@yahoo.co.id 
wajar apabila modernisme ini mulai dipertanyakan kembali keabsahannya oleh kebanyakan orang dengan memunculkan ide baru yang berupa post modernisme, sebagaimana yang disinyalir oleh John Naisbitt dan Patricia Aburdence, futurlog terkemuka dunia, pada era dekade tahun 90-an yang meramalkan bahwa abad ke21 merupakan era baru yang tidak terbantahkan dan secara signifikan berpengaruh terhadap berbagai kehidupan sosial termasuk pada pendidikan Islam. ${ }^{1}$

Pada konteks tersebut, peran pendidikan Islam dewasa ini diyakini sebagai benteng moral terakhir dari sistem pendidikan yang ada, sekaligus menjadi pusat peradaban dan perubahan sosial yang dituntut untuk memainkan perannya secara dinamis dan proaktif. Karena itu keberadaan pendidikan Islam diharapkan mampu memberikan kontribusi bagi perbaikan dan kemajuan peradaban umat Islam, baik pada tataran teoritis dan maupun praktis. Pendidikan Islam bukan hanya difahami sebagai transfer ilmu pengetahuan,tatapi yang paling urgen bagaimana sistem nilai sosial tersebut menjadi transformsi perubahan, sekaligus sebagai benteng moral dari akses negatif globalisasi dan modernisasi di tengah-tengah keragaman sosiokultural masyarakat yang pluralistik. Pada konteks tersebut, perkembangan sistem pendidikan Islam sebagaimana menurut Syafi'i Ma'arif, seperti yang dikutip Moh Shofan mengatakan pendidikan Islam telah melahirkan dua pola pemikiran yang kontradiktif. Keduanya mengambil bentuk yang berbeda, baik pada aspek materi, sistem pendidikan, atau dalam bentuk kelembagaan sekalipun. ${ }^{2}$ Dua model yang dimaksud adalah pendidikan Islam yang bercorak tradisionalis (ketimuran), dalam perkembangannya lebih menekankan pada aspek (doktriner-normatif) dan bersifat ekslusif-apologetis, sedangkan pada model kedua potret pendidikan Islam bersifat modernis dan dalam perkembagannya telah mulai kehilangan hal-hal yang bersifat transendental ${ }^{3}$.

Demikian, terlepas dari kedua model dimaksud, potret pendidikan Islam telah mengakibatkan terjadinya ambivalensi dan orientasi pendidikan Islam, ${ }^{4}$ yang salah satunya berdampak negatif dengan lahirnya paradigma dualisme-dikotomis. Karena itu, potret pendidikan Islam dewasa ini memerlukan sebuah perubahan dan pendekatan yang dapat mengintegrasikan antara model pendidikan Islam yang bercorak positivistik-rasionalistik dan religius-normatif. Demikian pada kajian ini penulis mencoba melakukan sebuah rekonstruksi dalam membingkai pendidikan Islam yang bersifat rahmatan lil'alamin.

1 Imam Tholkhah, Ahmad Barizi, Membuka Jendela Pendidikan: Mengurai Benang Tradisi Dan Integrasi Keilmuan Pendidikan Islam, (Jakarta: PT. RajaGrafindo Persada, 2004), h. 1.

${ }^{2}$ Moh. Shofan, Pendidikan Berparadigma Profetik, (Yogyakarta: IRCiSoD, 2004), h. 6.

3 Ahmad Fauzi, Membangun Epistemologi Pendidikan Islam Melalui Kepemimpinan Spiritual : Suatu Telaah Diskursif, (Empirisma STAIN Kediri, 24.2, 2015), h. 155-67.

${ }^{4}$ M Saifuddin, Desekularisasi Pemikiran, (Bandung: Mizan, 1998), h. 103. 


\section{B. Pembahasan}

\section{Paradigma Pendidikan Islam berbasis Rahmatan Lil'alamin}

Pada tataran realitas, eksistensi pendidikan Islam senantiasa bersentuhan dengan realitas sosial yang mengitarinya. Karena itu, secara sosiologis pendidikan Islam diharapkan mampu memainkan peranya secara dinamis dengan membawa visi universal (rahmatan lil'alamin) mengedepankan beberapa prinsip, antara lain; menjaga kerukunan, perdamaian, saling menghargai dan pembebasan (liberation), bukan sebagai domestikasi, penjinakan sosial (social and cultural domestication). ${ }^{5}$ Karena itu, secara normatif, Islam telah memberikan landasan bagi pelaksanaan pendidikan universal, yaitu mengembalikan nilai-nilai ajaran Islam yang (kaffah) sesuai dengan sosio-kultural masyarakat Indonesia dengan dilandasi nilai ilahiyah dan nilai kemanusiaan (insaniyah). Pandangan ini secara holistik didasarkan pada beberapa hal, antara lain: a) Islam menekankan pendidikan merupakan kewajiban agama dimana seluruh kegiatan pembelajaran dan transmisi ilmu sangat bermakna bagi manusia, ${ }^{6}$ b) seluruh rangkaian dari pelaksanaan pendidikan adalah ibadah kepada Allah, ${ }^{7}$ sebagai bentuk ibadah kepada-Nya, c) Islam memberikan derajat kepada orang-orang yang terdidik, ${ }^{8}$ d) Islam memberikan landasan, pendidikan sepanjang hayat, ${ }^{9}$ e) model pendidikan Islam bersifat dialogis, inovatif, inklusif dan toleran.

Karena itu, potret pendidikan Islam dewasa ini dihadapkan pada perubahan yang mendasar, terutama dalam mempersiapkan manusia yang mampu hidup dan berintegrasi dengan masyarakat yang pluralistik dengan beragam sosial-budaya yang berbeda. Demikian upaya untuk membangun potret pendidikan Islam dengan visi rahmatan lilalamin, dapat dilakukan melalui (grand project) yaitu; pendidikan Islam harus memiliki kualitas SDM dengan integritas dan moralitas yang tinggi serta mampu menganalisa isu-isu keagamaan yang sedang berkembang, landasan pendidikan yang selama ini difahami bersifat dikhotomik menjadi monokhotomik penyatuan ini dibingkai dengan nilai normatif sehingga dapat melahikan moralitas bagi setiap individu. Disamping itu, pendidikan Islam harus mampu menengahi pemahaman keagamaan Islam radikal, sering diklaim sebagai embrio munculnya ketidaknyamanan dalam masyarakat beragama yang multi etnis,

5 Andik Wahyun, Membangun Kesadaran Inklusif-Multikultura Deradikalisasi Pendidikan Islam. (Jurnal Pendidikan Islam UIN Sunan Kalijaga Jogjakarta, Vol. II, No 1, Juni 2013), h. 131

${ }^{6}$ Lihat Q.S. Al-Alaq, ayat: 1-5.

${ }^{7}$ Lihat Q S. Al-Hajj, ayat: 54.

${ }^{8}$ Lihat Q.S. Al-Mujadalah, ayat: 11 dan Q. S. Nahl, ayat: 43.

${ }^{9}$ Redja Mudyahardjo, Pengantar Pendidikan, (Jakarta: PT Raja Grafindo Persada, 2002), h. 169. 
ras dan agama ${ }^{10}$. Karena itu, pendidikan Islam berbasis rahmatan lil'alamin ini dipandang sebagai solusi kritis untuk melahirkan pendidikan Islam yang berpikiran moderat ${ }^{11}$.

\section{Internalisasi Nilai-Nilai Pendidikan Islam Rahmatan Lil'alamin}

Internalisasi nilai-nilai pendidikan Islam rahmatan lil'alaimn, merupakan seperangkat makna yang bersifat universal sekaligus menjadi social capital untuk mendorong, menggerakkan dan melahirkan tindakan sosial individu yang positif melalui beberapa pendekatan, antara lain: 1) Mentransmisikan keseluruhan sistem nilai sosial keagamaan berupa; ketauhidan, toleransi, keadilan dan persaudaraan ke-dalam kurikulum pendidikan. Karena kurikulum pada hakikatnya dipandang bagian penting dalam pembelajaran yang diharapkan dapat mempengaruhi prilaku individu dan sebagai (culture domination and control) untuk menentukan lulusan serta pembentukan ideologi setiap individu. ${ }^{12}$ 2) Mengedepankan metode dialogis dalam pembelajaran, sebagai nilai keyakinan (believe system) yang pada akhirnya menjadi legitimasi perubahan sosial di tengah-tengah keragaman masyarakat, dan model pembelajaran ini tidak hanya mengedepankan (transforms of knowledge), melainkan juga (transforms of attitude). 3) Menghilangkan paradigma dikotomi antara ilmu agama dan ilmu umum, karena paradigma ilmu tidak bebas nilai, melainkan bebas untuk dinilai, mengajarkan agama lewat ilmu pengetahuan, tidak hanya mengajarkan sisi tradisional melainkan juga rasionalitas. 4) Merubah paradigma pendidikan dari indoktrinasi menjadi partisipatif, model pembelajaran ini memberikan ruang bagi setiap individu untuk berpikir kritis, dinamis dan inovatif, 5) Merubah paradigma ideologis menjadi paradigma ilmiah dan berpijak pada wahyu Ilahiyah, dengan memberikan keleluasaan bagi akal manusia untuk dapat mengkaji, meneliti, melakukan observasi, menemukan ilmu pengetahuan, 6) merubah pendekatan teoritis menjadi pendekatan kontekstual, tetapi betapapun besarnya kekuatan akal untuk menjalankan proses berpikir,

\footnotetext{
${ }^{10}$ Hujair A. Sanaky, Permasalahan dan Penataan Pendidikan Islam Menuju Pendidikan yang Bermutu, (dalam Jurnal El-Tarbawi Jurnal Pendidikan Islam No. 1, Vol. 1 Tahun 2008), h. 85.

11 Ahmad Fauzi, 'Transkulturasi Social Capital Pesantren; Sebagai Paradigma Pendidikan Islam Moderat', (in 2St Annual Conference For Muslim Scholars, Strengthening The Moderate Vision of Indonesia Islam, Surabaya, 2018), h. 751-65.

12 Ahmed A.K, Pendidikan Pesantren dan Radikalisme; Tinjauan Perubahan Budaya Pesantren. (Jurnal Studi Islam, No 8, Vol 11, 2011), h. 11-18.
} 
bernalar, menggagas, dan berimajinasi untuk menemukan pengetahuan baru, tetapi posisi akal memiliki keterbatasan ${ }^{13}$.

Berbagai langkah tersebut, merupakan usaha untuk membangun paradigm pendidikan Islam berbasis rahmatan lil'alamin dan diharapkan dapat membuka diri bagi individu di tengah keragaman masyarakat. Karena itu peran pendidikan Islam mendorong lahirnya prilaku individu dengan memiliki wawasan global dan menerima adanya keberagaman, sehingga tidak ada lagi klaim kebenaran apalagi menyalahkan kelompok lain. Pada konteks tersebut, terdapat beberapa landasan pendidikan Islam holistik-integralistik dan bersumber pada beberapa aspek antara lain; kesatuan dalam aspek ketuhanan $^{14}$, kesatuan kenabian ${ }^{15}$, tidak ada paksaan dalam beragama ${ }^{16}$, dan pengakuan terhadap eksistensi agama lain ${ }^{17}$. Demikian sistem nilai dimaksud, masing-masing bersumber pada al-Qur'an yang berfungsi sebagai dasar penyelenggaraan pendidikan. Kesatuan ketuhanan dan Kenabian di atas merupakan landasan terwujudnya kecerdasan (spritualitas), sedangkan kedua dari keempat terakhir sebagai pijakan pembentukan kecerdasan emosionalitas. $^{18}$

Pada konteks tersebut, difahami bahwa landasan di atas memberikan ruang gerak bagi pendidikan Islam untuk melahirkan individu agar dapat mempunyai kepribadian pluralis dan moralis, disamping mampu mewujudkan prilaku individu yang mempunyai kepekaan sosial dan religius yang tinggi dalam menerima ilmu pengetahuan dan teknologi tanpa memandang kawasan tertentu. Demikian potret pendidikan Islam rahmatan lilalamin ini dipandang ideal dalam menunjang proses pembentukan individu menjadi pribadi yang demokratis, pluralis dan menekankan penghayatan hidup serta refleksi untuk menjadi manusia yang seutuhnya, yaitu individu yang tidak hanya pandai tetapi juga bermoral dan etis, dapat hidup dalam suasana demokratis satu dengan lain, dan menghormati hak orang lain. Karena itu, hakekatnya di era multikulturalisme dan pluralisme, dimana seluruh masyarakat dengan segala unsurnya dituntut untuk saling bergantung dan menanggung nasib secara bersama-sama demi terciptanya perdamaian abadi, dan salah satu bagian

13 Ahmad Fauzi, Persepsi Barakah Di Pondok Pesantren Zainul Hasan Genggong; Perspekstif Interaksionalisme Simbolik, (E-Jurnal Al-Tahril IAIN Ponorogo, 17. Islam Ortodoksi Heterrodoksi, 2017), 105-32.

${ }^{14}$ Lihat Q.S an-Nisa, ayat; 131., Q.S. Ali Imran ayat 64., dan Q.S. an- Nisa' ayat 163

${ }^{15}$ Lihat Q.S al-Anbiya, ayat: 73 dan Q.S. Ali Imran, ayat: 84

${ }^{16}$ Lihat Q.S al-Baqarah ayat 256

${ }^{17}$ Lihat Q.S al-Ma'idah, ayat: 69 dan 82

${ }^{18}$ Isma'il Raji al-Faruqi, The Role of Islam in Global Inter-Religious Defendence, dalam Ataullah Siddiqui, Islam and Other Faiths, (Horndon USA: The International Institute of Islam Thought, 1998), 74. Juga dalam Isma'il Raji Al-Faruqi, The Cultural Atlas of Islam, (New York: Macmillan, 1986), h. 190. 
penting dari konsekuensi kehidupan global yang ditandai dengan kemajemukan adalah membangun kembali dan menumbuhkan kembali teologi pluralisme dalam masyarakat, inilah potret dari potret pendidikan Islam berbasis rahmatan lilalamin, sebagaimana Islam sebagai agama dengan jelas tidak menolak adanya pluralisme, bahkan memberikan kerangka yang bersifat etis, hal ini tercermin dalam beberapa ayat al-Qur'an yang secara eksplisit mengakui kenyataan tersebut sebagai sesuatu yang bersifat sunnahtullah ${ }^{19}$.

Demikian kehadiran pendidikan Islam dewasa ini diyakini sebagai benteng moral terakhir dari segala sistem pendidikan yang ada, yang dipersepsikan sebagai instrumen penting sekaligus menjadi pusat perubahan sosial dan mampu menjadi (guiding light) bagi setiap individu. Karena itu, potret pendidikan Islam dituntut untuk memainkan perannya secara dinamis dan proaktif, sekaligus sebagai media penyadaran dalam membangun teologi konstruktif, demi terciptanya harmonisasi kehidupan sosial yang pluralistik sesuai dengan kondisi masyarakat di Indonesia. Pada konteks tersebut, Alex R. Rodger menjelaskan bahwa, peran pendidikan agama merupakan bagian integral dari pendidikan pada umumnya yang berfungsi untuk menumbuhkan sikap saling pengertian bagi setiap pemeluknya, sekaligus juga untuk memperkuat ortodoksi keimanan bagi dirinya. ${ }^{20}$ Demikian pendidikan Islam berbasis rahmatan lil'alaimin ini sebagai wahana untuk mengekplorasi sifat dasar keyakinan agama dalam proses pendidikan dan mempertanyakan adanya bagian dari pendidikan keimanan di tengah-tengah masyarakat. Pendidikan agama Islam dengan begitu, harus mampu merefleksikan persoalan pluralisme, dengan mentransmisikan nilai-nilai yang dapat menumbuhkan sikap toleran, terbuka dan kebebasan.

Pandangan tersebut sebagaimana telah dibuktikan dalam sejarah peradaban Islam, bahwa perkembangan dan kemajuan Islam tidak dapat dilepaskan dari dua hal, yaitu; pertama, internalisasi nilai-nilai sosial masyarakat yang terbuka (open society) sehingga menghasilkan kontak dengan kebudayaan-kebudayaan lain, dan hal ini melahirkan nilai baru yang lebih modern dan egaliter. Kedua, humanisme; melahirkan sikap perhatian terhadap masalah hubungan dan interaksi antar sesama manusia. Pada konteks tersebut, manusia memiliki otoritas yang lebih luas dalam menentukan makna hidupannya. Kedua sistem nilai tersebut, menjadi spirit dalam membangun peradaban Islam, karena itu sistem nilai seperti sikap terbuka, toleran dan kebebasan menjadi prinsip dasar di dalam mewujudkan pendidikan berbasis

${ }^{19}$ Syamsul Arifin dan Ahmad Barizi, Paradigma Pendidikan Berbasis Pluralisme dan Demokrasi: Rekonstruksi dan Aktualisasi Tradisi Ikhtilaf dalam Islam, (Malang: UMM Press, 2001), h. 02.

${ }^{20}$ Alex R. Rodger, Educational and Faith in Open Society, (Britain: The Handel Press, 1982), h. 61 . 
rahmatan lil'alamin. Demikian pendidikan Islam dimaksud, dibangun berdasarkan landasan yang kokoh dan bersifat universal, sebagai pijakan, sekaligus tujuan dan evaluasi terhadap keberhasilan dari pendidikan Islam sendiri, ${ }^{21}$ misalnya adanya etika profetik penyelenggaraan dan pengembangan pendidikan Islam, antara lain; a) Nilai Ibadah, sebagai praktisi dan pengelola pendidikan Islam, pengembangan dan penerapannya dinilai sebagai bentuk ibadah kepadaNya ${ }^{22}$; b) Nilai Ihsan, pendidikan Islam hendaknya dikembangkan untuk berbuat baik kepada sesamanya dan disebabkan karena Allah telah berbuat baik kepada manusia dengan berbagai nikmat-Nya, dan dilarang berbuat kerusakan ${ }^{23}$; c) Nilai masa depan, pendidikan Islam hendaknya ditujukan untuk mengantisipasi masa depan yang lebih baik, karena mendidik berarti menyiapkan generasi yang akan hidup dan menghadapi tantangan masa depan yang jauh berbeda dengan generasi sebelumnya $^{24}$; d) Nilai rahmat, pendidikan Islam hendaknya ditujukan bagi kemaslahatan seluruh umat manusia ${ }^{25}$; e) Nilai amanah, pendidikan Islam difahami sebagai amanah dari-Nya, sehingga proses pengembangan-nya dapat dilakukan dengan niat, cara dan tujuan sebagaimana yang dikehendaki-Nya ${ }^{26}$; f) Nilai dakwah, potret pengembangan pendidikan Islam merupakan wujud dialogis dakwa menyampaikan kebenaran tentang Agama Islam ${ }^{27}$; g) Nilai tabsyir, pendidikan Islam senantiasa memberikan harapan baik kepada umat manusia tentang masa depan, termasuk dalam menjaga keseimbangan dalam melestarikan kehidupan yang harmoni. ${ }^{28}$ Demikian bahwa, nilai pendidikan Islam dimaksud, merupakan sebuah perpaduan antara ruhiyah, fikriyah (pemahaman, pemikiran) dan amaliyah, kemudian dikembangkan kepada pemberdayaan di segala sektor kehidupan manusia dengan memasuki berbagai bidang kehidupan, ${ }^{29}$ yang berlandaskan pada keimanan untuk beribadah kepada Allah SWT, sehingga bertindak sesuai dengan ilmu pengetahuan, dan berprilaku terpuji.

\section{Mambangun Epistemologi Pendidikan Islam}

21 Muhaimin, Nuansa Baru Pendidikan Islam: Mengurai Benang Kusut Dunia Pendidikan, (Jakarta: Rajawali Press, 2006), h. 67

${ }^{22}$ Lihat Q.S Al-Dzariyat, ayat: 56 dan Q.S. Ali Imran, ayat: 190-191

${ }^{23}$ Lihat Q.S Al-Qashah, ayat: 77

${ }^{24}$ Lihat Q.S Al-Hasyr, ayat: 18.

${ }^{25}$ Lihat Q.S Al-Anbiyaa, ayat: 107

${ }^{26}$ Lihat Q.S Al-Ahzab, ayat: 72

${ }^{27}$ Lihat Q.S Fushshilat, ayat: 33

${ }^{28}$ Lihat Q.S Al-Baqarah, ayat: 119

${ }^{29}$ Lihat Q.S Ali Imran, ayat: 103 
Epistemologis, ${ }^{30}$ dalam pendidikan Islam dimaksudkan sebagai kerangka dalam membangun paradigma pendidikan Islam berbasis (rahmatan lil'alamin). Kajian ini menyediakan ruang untuk memperdebatkan persoalan filosofis yang tidak dapat dijawab oleh wilayah ilmu, karena sifat ilmu menjunjung sakralitas nilai-nilai ilmiah dengan mendasarkan pada wilayah fisik dan empirik. Perdebatan dalam wilayah kajian epistemologi pendidikan Islam, dalam perspektif Muhaimin menyangkut pengembangan potensi dasar manusia (fitrah) pewarisan budaya, dan interaksi antara potensi dan budaya. Pada tataran praktis juga memperdebatkan masalah kurikulum pendidikan, metode, pendidik dan peserta didik, ${ }^{31}$ termasuk mempertanyakan paradigma pendidikan Islam berbasis (rahmatan lilalamin) yang berkaitan dengan persoalan konsep dasar sekaligus metodologisnya. Karena itu, secara universal jika subtansi pendidikan Islam menuntut sebuah paradigma, pada konteks tersebut Munir Mulkhan menjelaskan bahwa, problem epistemologis dan metodologis pemikiran Islam juga merupakan problem dari pendidikan Islam. $^{32}$

Demikian, epistemologi pendidikan Islam berbasis rahmatan lilalamin ini lebih diarahkan pada metode-pendekatan yang dapat dipakai untuk membangun paradigma ilmu pengetahuan tentang potret pendidikan Islam dimaksud, dari pada beberapa komponen lainnya. Karena itu, metode dan pendekatan tersebut paling dekat dengan upaya mengembangkan pendidikan Islam yang berbasis rahmatan lil'alamin, baik secara konseptual maupun aplikatif. Epistemologi pendidikan ini diharapkan dapat diimplementasikan dalam kegiatan belajar mengajar di lembaga pendidikan Islam, sehingga dapat melahirkan beberapa konsekuensi logis, yaitu: 1) menghilangkan paradigma dikotomi antara ilmu agama dan ilmu umum, ilmu tidak bebas nilai, tetapi bebas untuk dinilai, mengajarkan agama lewat bahasa dan ilmu pengetahuan, tidak mengajarkan sisi tradisional saja, tetapi sisi rasional. 2) merubah pola pendidikan Islam indoktrinasi menjadi pola partisipatif antara guru dan murid, yaitu memberikan ruang gerak bagi peserta didik untuk berpikir kritis, optimis, dinamis, inovatif, memberikan alasan-alasan yang logis, bahkan peserta didik dapat pula mengkritisi pendapat guru jika terdapat kesalahan. 3) merubah paradigma ideologis menjadi paradigma ilmiah yang berpijak pada wahyu. Karena itu paradigma ideologis ini otoritasnya dapat mengikat kebebasan tradisi ilmiah, kreatif, terbuka, serta berfikit dinamis. 4)

${ }^{30}$ Musa Asy’ari, Filsafat Islam: Sunnah Nabi Dalam Berpikir, (Yogyakarta: LESFI, 1999), h. 65.

${ }^{31}$ Muhaimin, Pengembangan Kurikulum Pendidikan Agama Islam: di Sekolah, Madrasah dan Perguruan Tinggi, (Jakarta: Raja Grafindo Persada, 2005), h. 66.

${ }_{32}$ Abdul Munir Mulkhan, Paradigma Intelektual Muslim: Pengantar Filsafat Pendidikan Islam dan Dakwah, (Yogyakarta: SIPRES, 1993), h. 213. 
merekonstruksi model kurikulum yang masih dianggap sekuler dan bebas nilai, menjadi kurikulum yang berbasis tauhid. 5) epistemologi pendidikan Islam diorientasikan pada hubungan yang harmonis antara akal dan wahyu ${ }^{33}$.

Demikian konsekuensi logis dari pendekatan epistemologis di atas, bahwa sumber ilmu pengetahuan -cara memperoleh ilmu pengetahuan-dalam perspektif Mujamil Qomar, hanya dapat diperoleh melalui proses setelah ia mengalami yang lebih dikenal oleh Imam Al-Ghazali dengan ilmu (nazari), sedangkan jika di Barat lebih dikenal dengan (empirisme),yang bersumber pada kekuatan indera manusia sedangkan kedua bersumber pada kekuatan akal. Pandangan tersebut, berbeda dalam Islam, sumber pengetahuan berasal dari wahyu Ilahiyah dan Hidayah Allah SWT, yang memiliki otoritas kebenaran mutlak. ${ }^{34}$ Karena itu, betapapun kekuatan akal untuk menjalankan proses berpikir dan menemukan pengetahuan baru, tetapi perlu ditegaskan lagi bahwa akal memiliki keterbatasan. Demikian epistemologi pendidikan Islam harus melakukan berbagai perubahan dibidang kurikulum dan hal ini dapat dilakukan sebagai berikut, antara lain; 1) membangun epistemologi berpijak pada al-Qur'an dan al-Hadits yang didesain dengan mempertimbangkan konsep ilmu pengetahuan, islamisasi ilmu pengetahuan dan karakter ilmu dalam perspekti Islam yang bersandar pada kekuatan spiritual yang memiliki hubungan harmonis antara akal dan wahyu, interdependensi akal dengan intuisi yang terkait nilai-nilai spiritual. Episemologi Pendidikan Islam ini, menjadi tumpuan harapan dalam membangun kehidupan umat Islam yang lebih baik dengan suatu peradaban Islam yang lebih mapan dan stabil. 2) memperioritaskan epistemologi pendidikan Islam yang berbasis proses tauhid, pengalaman empirik, di mana dari realitas empirik ini kemudian diamati, dikaji, dan diteliti dengan mengandalkan metode observasi dan eksperimentasi disertai dengan spirit tauhid keimanan. Langkah ini menekankan bahwa epistemologi harus dimaknai sebagai proses, prosedur, cara kerja metodologi penelitian guna mencapai pengetahuan baru, bukan epistemologi dalam makna sumber atau alat untuk mencapai pengetahuan. Kemudian, muatan teologis atau hegemoni teologi atas epistemologi harus dihilangkan sedemikian rupa sehingga epistemologi menjadi independen atau berdiri sendiri. 3) orientasi atau penekanan pada knowing pengetahuan teoritik yang menjadikan peserta didik pasif dalam belajar di bawah otoriter guru, perlu dirubah ke orientasi epistemologi pendidikan Islam yang menekankan pada doing, aktivitas dan kreativitas, atau kerja profesional yang menjadikan peserta didik aktif dan

${ }^{33}$ Fauzi Ahmad, Pendidikan Inklusif Berbasis Kearifan Lokal Dalam Praktik Sosial Di Pesantren Zainul Hasan Genggong Probolinggo Jawa Timur, (Proceedings Ancoms 1St Annual Conference For Muslim Scholars, 2.110, 2017), h. 715-25.

${ }^{34}$ Mujamil Qomar, Epistemologi Pendidikan Islam Dari Metode Rasional Hingga Metode Kritik, (Jakarta: Erlangga, 2005), h. 262. 
kretif dalam kegiatan belajar. Dalam proses doing, aktivitas, kreativitas tersebut nilai-nilai spiritual dan moralitas masuk di dalamnya, sehingga disamping peserta didik menemukan ilmu pengetahuan baru dia juga dapat mengakses nilai-nilai spiritual secara bersamaan. 4) mengembangkan pendekatan yang lebih mencerdaskan peserta didik dari pada pendekatan tradisional yang menekankan pendekatan hafalan, yang dipergunakan untuk memperoleh ilmu pengetahuan dengan menggunakan pertimbangan atau kriteria kebenaran memalui proses berpikir yang bisa diterima oleh $\mathrm{akal}^{35}$.

\section{Model Konstruksi Pendidikan Islam Berbasis Rahmatan Lil'alamin}

Dinamisasi pendidikan Islam dewasa ini menuntut adanya perubahan yang mendasar di segala bidang, sesuai dengan tantangan globalisasi termasuk kondisi sosial masyarakat yang pluralistik. Karena itu, menuntut pendidikan Islam untuk memainkan perannya secara dinamis, menjadi garda terdepan untuk memberikan pencerahan sosial-kultural kepada masyarakat sesuai dengan visi Islam rahmatan lil'alamin. Karena pada hakikatnya, pendidikan Islam dibangun berdasarkan nilai-nilai universal yang berasal dari al-Qur'an dan al Hadits. Dalam konteks tersebut, Islam menuntut adanya berbagai perubahan mendasar terhadap pendidikan Islam, dengan menyediakan ruang terbuka untuk melakukan dialogis, mengangkat nilai-nilai kemanusiaan universal berupa (mahabbah, ijtima'iyyah, musawah, 'adalah dan ukhuwah). Karena itu diperlukan sebuah upaya untuk membangun paradigma pendidikan Islam rahmatan lilalamin, melalui nilai- nilai sosial dimaksud.

Dalam perspektif teori konstruksi sosial (social construction of reality) Peter L Berger dan Thomas Luckman, menegani dialektika antara (ekternalisasi objektivasi dan internalisasi) digunakan untuk membangun paradigma pendidikan Islam berbasis rahmatan lil'alamin. Karena itu melalui (eksternalitas) bagaimana sistem nilai tersebut dibangun berdasarkan tradisi keilmuan pendidikan Islam, yang bermuara pada al-Qur'an dan al-Hadits, dari proses di atas bagaimana peran individu mampu menciptakan realitas sosial dan menjadi sesuatu yang bersifat objektif, ${ }^{36}$ pandangan ini kemudian melahirkan sebuah sistem nilai (internalisasi) berupa berupa (mahabbah, ijtima'iyyah, musawah, 'adalah dan ukhuwah) sebagai sesuatu yang terlembagakan. Dalam teori konstruksi sosial, internalisasi nilai-nilai tersebut diyakini sebagai produk yang di bangun oleh lembaga pendidikan Islam,

35 Ahmad Fauzi, Manajemen Pendidikan Islam Di Pesantren; Berbasis Kearifan Lokal Kajian Fenomenologis, (Seminar Nasional Pendidikan, Fakultas Ilmu Pendidikan Universitas Negeri Malang, Sinergitas Keluarga, Sekolah, Masyarakat dalam Penguatan Pendidikan Karakter, Malang, 2017), pp. h. 51-62.

36 Andrew Giddings, Elements of Sociological Theori of Religion, (Sacred Canopy, Oktober, 2000), h. 56. 
melalui peran dan tindakan individu di selilingnya (reality is socially constructed) Konsepsi tersebut berakar dari paradigma konstruktivis yang melihat realitas sosial sebagai sesuatu yang diciptakan melelui peran sosial individu, sehingga ia menjadi penentu dunia sosialnya, yaitu berdasarkan kehendak serta kemauannya. Konstruksi pendidikan Islam berbasis rahmatan lil'alamin ini digunakan untuk menjelaskan bagaimana tindakan dan peran individu di tengah-tengah masyarakat yang pluralistik mampu melahirkan sistem nilai sebagai bagian dari yang mereka ciptakan

Demikian internalisasi nilai-nilai dimaksud ${ }^{37}$, menjadi modal sosial bagi lembaga pendidikan Islam -madrasah maupun pesantren- untuk membangun model pendidikan inklusif-moderat berbasis rahmatan lil'alamin. Karena secara sosiologis peran pendidikan Islam telah menunjukkan kirpahnya di tengah-tengah kehidupan sosial melalui sistem nilai yang dibangun. Habitualisasi nilai-nilai sosial dimaksud, merupakan seperangkat makna yang bersifat universal (kaffah) untuk mendorong, menggerakkan, mempengaruhi dan melahirkan tindakan sosial individu yang positif melalui beberapa pendekatan, yaitu: 1) mentransmisikan keseluruhan sistem nilai sosial keagamaan berupa ketauhidan, toleransi, keadilan dan nilai persaudaraan ke-dalam kurikulum. Karena pada hakikatnya kurikulum dipandang sebagai bagian penting dalam kegiatan pembelajaran yang mampu mempengaruhi prilaku sosial individu sekaligus sebagai (culture domination and control) untuk menentukan lulusan serta pembentukan ideologi peserta didik yang inklusif $^{38}$, 2) mengedepankan metode dialogis dalam setiap pembelajaran sebagai nilai keyakinan (believe system) yang pada akhirnya menjadi legitimasi perubahan sosial di tengah-tengah masyarakat yang pluralistik, model pembelajaran tersebut tidak hanya mengedepankan (transforms of knowledge), tetapi juga (transforms of attitude). 3) merubahan pola pembelajaran indoktrinasi dengan menempatkan individu sebagai objek belajar, karena ia dipandang sebagai (take for granted),4) menghilangkan paradigma dikotomi antara ilmu agama dan ilmu umum. Karena paradigma ilmu tidak bebas nilai, melainkan bebas untuk dinilai, mengajarkan agama lewat pengetahuan, tidak hanya mengajarkan sisi tradisional melainkan juga rasionalitas, 5) merubah paradigma pendidikan dari indoktrinasi menjadi partisipatif, model ini memberikan ruang bagi setiap individu untuk berpikir kritis, dinamis dan inovatif, 6) merubah paradigma ideologis menjadi ilmiah, berpijak pada wahyu Ilahiyah, dengan memberikan keleluasaan bagi akal

37 Ahmad Fauzi, Pengembangan Human Relation Perspektif Nilai-Nilai Al-Qur'an', (Mutawatir UIN Sunan Ampel Surabaya, 1.2, 2015), h. 168-79.

38 Ahmed A.K, Pendidikan Pesantren dan Radikalisme; Tinjauan Perubahan Budaya Pesantren. (Jurnal Studi Islam, No 8, Vol 11, 2011), h. 11-18. 
manusia untuk mengkaji, meneliti, melakukan observasi, menemukan pengetahuan, 7) merubah pendekatan teoritis menjadi pendekatan kontekstual, tetapi betapapun besarnya kekuatan akal untuk menjalankan proses berpikir, bernalar, menggagas untuk menemukan pengetahuan baru, posisi akal memiliki keterbatasan.

Berbagai langkah tersebut, merupakan usaha untuk melahirkan prilaku individu, melalui sistem nilai (believe system) dan diharapkan dapat membuka diri bagi individu di tengah keragaman masyarakat. Karena itu peran pendidikan Islam mendorong lahirnya prilaku sosial individu dengan memiliki wawasan global dan menerima terhadap keberagaman, sehingga tidak ada lagi klaim kebenaran dan menyalahkan kelompok lain. Pada konteks inilah, secara faktual pendidikan Islam telah terbukti memainkan perannya dalam dinamika kehidupan sosial masyarakat Indonesia dan membawa perubahan besar, ${ }^{39}$ sebagaimana Azra menyatakan, peran pendidikan Islam setidaknya berada dalam tiga hal, antara lain; pertama,transmisi pengetahuan Islam dari guru kepada peserta didik, kedua, berpegang teguh pada tradisi Islam klasik, ketiga, mempersiapkan peserta didik sebagai reproduksi ulama atau calon intelektual muslim.

\section{Penutup}

Pendidikan Islam dewasa ini dihadapkan pada tantangaan yang sangat krusial seiring dengan berkembangnya arus globalisasi, karena itu kehadiran pendidikan Islam secara signifikan telah memberikan kontribusi terhadap realitas sosial di tengah-tengah masyarakat, pandangan tersebut tidak lepas dari peran pendidikan Islam sebagai benteng moral terakhir dari segala sistem pendidikan di Indonesia. Secara sosial kehadiran pendidikan Islam melahirkan nilai-nilai sosial, yang diyakini mampu menjadi nilai dasar (core belief and core values) terhadap potret pendidikan Islam berbasis rahmatan lil'alamin. Demikian untuk melahirkan potret pendidikan Islam dimaksud, diperlukanlah bangunan konseptual, melalui teori konstruksi sosial (social construction),yaitu antara dialektika (ekternalisasi, objektivasi dan internalisasi).

Pendidikan Islam rahmatan lil'alamin melahirkan dua model pendidikan; a) potret pendidikan Islam ini dipandang sebagai pencerahan (enlightment) sosiokultural, b) paradigma pendidikan Islam tidak dapat dilepaskan oleh sosio-kultural masyarakat, yang turut mewarnai potret pendidikan Islam dewasa ini. Karena itu, upaya untuk membangun paradigma pendidikan dimaksud, maka diperlukanlah konstruksi sosial (social construction), dengan cara mengembalikan nilai-nilai pendidikan Islam secara universal (kaffah) yang bersifat dinamis melalui beberapa

${ }^{39}$ M astuki HS \& M Ishom el-Saha, Intelektualisme Pesantren: Potret Tokoh dan Cakrawala Pemikiran di Era Perkembangan Pesantren, (Jakarta: Diva Pustaka, 2003), 1. 
tahapan, yaitu: 1) membangun kesadaran individu dengan cara mentransmisikan keseluruhan sistem nilai keagamaan, seperti ketauhidan dan toleransi, keadilan ke dalam struktur kurikulum, 2) habitualisasi nilai-nilai pendidikan Islam ini menjadi dasar dalam mambangun paradigma pendidikan Islam rahmatan lil'alamin, 3) merubah paradigma pendidikan Islam dari cara pandang indoktrinasi menjadi partisipatif, 4) merubah paradigma ideologis menjadi paradigma ilmiah dengan memberikan keleluasaan bagi akal manusia untuk mengembangkan pengetahuan dengan petunjuk-Nya. Demikian, pandangan ini secara umum diharapkan menjadi landasan konseptual pendidikan Islam berbasis rahmatan lil'alamin dengan cara mentranformasikan nilai-nilai sosial di tengah-tengah keberagaman masyarakat. 


\section{DAFTAR PUSTAKA}

Ahmad, Fauzi, 'Pendidikan Inklusif Berbasis Kearifan Lokal Dalam Praktik Sosial Di Pesantren Zainul Hasan Genggong Probolinggo Jawa Timur', Proceedings Ancoms 1St Annual Conference For Muslim Scholars, 2 (2017), 715-25

Fauzi, Ahmad, 'Manajemen Pendidikan Islam Di Pesantren; Berbasis Kearifan Lokal Kajian Fenomenologis', in Seminar Nasional Pendidikan, Fakultas Ilmu Pendidikan Universitas Negeri Malang Sinergitas Keluarga, Sekolah Dan Masyarakat Dalam Penguatan Pendidikan Karakter (Malang, 2017), pp. 51-62

'Membangun Epistemologi Pendidikan Islam Melalui Kepemimpinan Spiritual : Suatu Telaah Diskursif', Empirisma STAIN Kediri, 24 (2015), $155-67$

—- 'Pengembangan Human Relation Perspektif Nilai-Nilai Al-Qur'an', Mutawatir UIN Sunan Ampel Surabaya, 1 (2015), 168-79

—_, 'Persepsi Barakah Di Pondok Pesantren Zainul Hasan Genggong; Perspekstif Interaksionalisme Simbolik', Al-Tahril IAIN Ponorogo, 17 (2017), 105-32

, 'Transkulturasi Social Capital Pesantren; Sebagai Paradigma Pendidikan Islam Moderat', in 2St Annual Conference For Muslim Scholars, Strengthening The Moderate Vision of Indonesia Islam, Surabaya, 2018), II, 751-65

A. M. Saifuddin, Desekularisasi Pemikiran, Bandung: Mizan, 1998.

A. Malik Fadjar, Visi Pembaharuan Pendidikan Islam, Jakarta: LP3NI, 1998.

Abdul Munir Mulkhan, Paradigma Intelektual Muslim: Pengantar Filsafat Pendidikan Islam dan Dakwah, (Yogyakarta: SIPRES, 1993).

Alex R. Rodger, Educational and Faith in Open Society, Britain: The Handel Press, 1982.

AM. Saefuddin, Desekularisasi Pemikiran: Landasan Islamisasi, Bandung: Mizan, 1993.

Etienne Gilson, Tuhan di Mata Para Filosuf, Peterj.: Silvester Goridus Sukur, Bandung: Mizan, 2004. 
H.A.R. Tilaar, Multicultural Education and Its Challenges in Indonesia, makalah pada International Seminar on Multicultural Education, Cross Cultural Understandding for Democracy and Justice, Yogyakarta 26 Agustus 2005.

Harold H. Titus dkk, Persoalan-Persoalan Filsafat, Peterj.: M. Rasyidi, Jakarta: Bulan Bintang, 1984

Hujair A. H. Sanaky, Permasalahan dan Penataan Pendidikan Islam Menuju Pendidikan yang Bermutu, dalam Jurnal El-Tarbawi Jurnal Pendidikan Islam No. 1, Vol. 1 Tahun 2008.

Hujair AH. Sanaky, Paradigma Pendidikan Islam: Membangun Masyarakat Madani Indonesia, Yogyakarta: Safiria Insani Press, 2003.

Imam Tholkhah dan Ahmad Barizi, Membuka Jendela Pendidikan: Mengurai Benang Tradisi Dan Integrasi Keilmuan Pendidikan Islam, Jakarta: PT. RajaGrafindo Persada, 2004.

Isma'il Raji al-Faruqi, On The Nature of Islamic Da'wah, dalam International Review of Mission, Vol. LXV, No. 260, October 1976.

Isma'il Raji Al-Faruqi, The Cultural Atlas of Islam, New York: Macmillan, 1986.

Isma'il Raji al-Faruqi, The Role of Islam in Global Inter-Religious Defendence, dalam Ataullah Siddiqui, Islam and Other Faiths, Horndon USA: The International Institute of Islam Thought, 1998.

Jerome Bruner, Proses Pendidikan: Upaya Pembenahan Pendidikan, Jakarta: Binarupa Aksara, 1994.

John Sealy, Religious Education Philosophical Perspective, London: George Allen \& Unwin, 1985.

Kemas Badaruddin, Filsafat Pendidikan Islam, Yogyakarta: Pustaka Pelajar, 2007

Moh. Shofan, Islamisasi Ilmu Pengetahuan, dalam Logos, Jurnal Ilmu-Ilmu Sosial dan Humaniora, Vol.4, No.1 Januari 2005.

Moh. Shofan, Pendidikan Berparadigma Profetik, Yogyakarta: IRCiSoD, 2004.

Muhaimin, Nuansa Baru Pendidikan Islam: Mengurai Benang Kusut Dunia Pendidikan, Jakarta: Rajawali Press, 2006.

Muhaimin, Pengembangan Kurikulum Pendidikan Agama Islam: di Sekolah, Madrasah dan Perguruan Tinggi, Jakarta: Raja Grafindo Persada, 2005.

Mujamil Qomar, Epistemologi Pendidikan Islam Dari Metode Rasional Hingga Metode Kritik, Jakarta: Erlangga, 2005. 
Noer Huda, Islam Nusantara: Sejarah Intelektual Islam Di Indonesia, Yogyakarta: Ar-Ruzz Media, 2007.

Redja Mudyahardjo, Pengantar Pendidikan, Jakarta: Raja Grafindo Persada, 2002

S. Nasution, Asas-Asas Kurikulum, Jakarta: Bumi Aksara, 1999.

Syamsul Arifin dan Ahmad Barizi, Paradigma Pendidikan Berbasis Pluralisme dan Demokrasi: Rekonstruksi dan Aktualisasi Tradisi Ikhtilaf dalam Islam, Malang: UMM Press, 2001.

William C. Chittic, The Islamic Concept of Human Perfection, T.kt.: The World \& I, 1991.

Zainal Abidin Bagir, dkk, Integrasi Ilmu dan Agama: Interpretasi dan Aksi, Bandung: Mizan Pustaka, 2005. 